Tattva, Vol. 3, No. 1, January - June 2017, pp. 35-50

ISSN 0975-332X | https://doi.org/10.12726/tjp.5.3

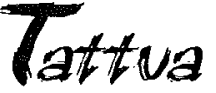

JOURNAL OF PHILOSOPHY

\title{
THE SACRED IN CREATION AND THE GOD-INTOXICATED CELT?
}

\section{Una Agnew, Ph.D}

The sense of an all-pervasive God, dynamically active in creation and involved in the everyday tasks of domestic life and work has come to be recognized as a dominant theme in Gaelic Christianity. I say Gaelic because the sources on which I lean most heavily are drawn primordially from Gaelic sources, which are of course Celtic in origin.' An acute sense of the nearness of God in everyday life especially among rural communities still survives in many places on the fringes of Western Europe. ' 'God's help is nearer than the door' is a Gaelic saying used in common parlance, ['is goire cabhair Dé ná an doras']. This proverb used by lrish speaking people who live close to the land, though it may not be currently the catchword of Irish politicians and bankers who live on the brink of bankruptcy.

1 Gaelic flourished as a spoken language in the outer Hebridies of Scotland and is still spoken on the Western and North-Western seaboards of Ireland; both of these countries spoke a similar branch of Gaelic: Q- Celtic while the Welsh language is derived from P-Celtic: both are drawn from the same Indo-European stock. Though the spoken language has diminished, Ireland still has a fully functioning Television station, $T$ na $G$ whose programmes are transmifted in Gaelic.

2 J Macquarrie, Paths in Spirituality, Oxford: Oxford University Press, 1972, 122-123 This Scottish theologian suggests that this renewed sense of God might be acquired through a renewed vision of the world and of human life itself such as that found in Celtic Christianity. 


\section{Daily round of Prayers}

In order to understand what is still residual and attracting more and more attention today under the brand name of Celtic Spirituality, it is necessary to examine a genre of Christianity which practiced constant invocation of an immanent God with hints of mystical orientation. A number of ancient morning prayers which greeted God's presence in the new day, still live orally in the Gaelic language and have survived into the 21 st century. These prayers have become popular today and are appearing in new translations and sung as hymns set in ancient musical tradition. These prayers originate from an ancient Gaelic oral tradition:

I am bending my knee in the eye of the Father who created me

In the eye of the Son who purchased me

In the eye of the Spirit who cleansed me

Love towards God

The affection of God

The smile of God

The wisdom of God...

And I'm asking the Three that my living shall be

In the likeness of Jesus my Lord.

Focusing on the eye of God is not a peculiarly Irish phenomenon. But this prayer shows an unmistakable sense of reverence under the eye of God, towards each person of the Trinity along with the desire to conform one's life 'in the likeness of Jesus' the Lord. The majestic eye of God is watchful while the smile and affection of God reassures. The God who sees is also the One, whose radiance endows all creation with blessedness. Traces of the same omni present immanent God, though always with a strong Trinitarian invocation, survive in and array of daily prayers that have been collected from the rural people of Ireland and Scotland. ${ }^{3}$ These cover every aspect of a person's day, from the moment of rising, at the kindling of the fire:

I will kindle my fire this morning

In the presence of the holy angels of heaven...

God kindle thou in my heart within

A flame of love to my neighbour

To my foe, to my friend, to my kindred all...

3 Alexander Carmichael, Carmina Gadelica, Hymns and Incantations, with Illustrative Notes of Words, Rites and Customs, Dying and Obsolete, Orally Collected in the Highlands and Islands of Scotland, 6 Vols, (The Scottish Academic Press, 1900-1954) See also Diarmuid Ó Laoghaire, SJ, Ár bPaidreacha Dúchais, Dublin: FÁS, 1975. 
Similar prayers were said while milking, fishing, sowing, before eating, when greeting, journeying, spinning yarn, lighting the lamp, smooring the fire and going to rest. An everyday greeting in Gaelic is not 'Good Morning', 'Hi' or 'Hello' it is a prayer: 'May God and Mary bless you' (Dia is Muire Dhuit) which shows how far Christianity penetrated into the language and culture of a people. Scholars such as Alexander Carmichael and the Irish Jesuit, Diarmuid Ó Laoghaire SJ who collected these prayers in Gaelic, found them in abundance in the outer Hebridies of Scotland and on the Western and Northern seaboards of Ireland; both of these countries spoke a similar branch of Gaelic, Q- Celtic while the Welsh language is derived from ' $P$ ' Celtic: all are drawn from the same Indo-European stock. From these hundreds of prayers collected and written down, it is clear that each aspect of daily life, each physical feature of creation is seen and reverenced as an integral part of a God-filled universe:

Bless to me $O$ God the moon that is above me

Bless to me $O$ God the earth beneath my feet.

Bless to me $O$ God my wife and my children

And bless to me $O$ God myself who have care of them

The Scottish theologian John Macquarrie, summed up the Celtic people as 'Godintoxicated', possessed of a visionary sense of the earth and retaining a holistic attitude toward Earth. ${ }^{4}$

The purpose of this article is to attempt to examine what John Macquarrie call the phenomenon of 'God-intoxication' present in Celtic Spirituality, and trace its potential mystical influence in some aspects of Celtic and Irish Christianity. ${ }^{5}$ However elusive these spiritual qualities may be today in the midst of Western materialism, it is clear that ancient Irish folklore was possessed of a sense of mystery and divine presence that is still never too far away from many rural Irish people. Difficult situations were often dealt with equanimity with the reassuring statement that: 'God is strong and has a good mother'. St Brigid, above other Irish saints, was given pride of place in the home by being hailed 'Mary of the Gael'. She is the miracle worker in the home, protector of the household, often invoked in hearth prayers and in anything to do with child-birth, fertility and the health of domestic animal. Her distinctive crosses, still fashioned from rushes every year on the eve of her feast Feb 1st, are placed over doors and outhouses as symbols of her profection.

4 John Macquarrie, Paths in Spirituality (Oxford: Oxford University Press, 1972) quoted by Sean Ó Duinn (2000) 7.

5 Seán Ó Duinn, Where Three Streams Meet: Celfic Spirituality, Dublin: The Columba Press, 2000. 
In the earlier pagan dispensation, the elemental gods and goddesses of our pagan past, who ruled over mountains, rivers and seas, produced in people a fear of incurring their displeasure and a desire to bend to their demands. The fear could only be assuaged by incantations, charms and spells and constant watchfulness. This fear was carried over into Christian practice and produced both positive and negative effects. In some cases religiosity degenerated into an occultist belief in superstitious practices such as that of carrying an animal claw for protection or hanging a rag on a bush near a holy well for protection. Similar fetishes were coupled with the urge to manipulate 'secret wisdom' and sacred power by means of magical practices around totemic objects, places and practices. We still have them around the festival of May I st when people danced with a May bush to drawn down fertility on animals and land and on St Stephen's day when the wren was carried in triumph ${ }^{6}$....And so, side by side with authentic religious practice, there developed a culfure of incantations, charms, spells and the concocting of magical potions to protect from danger or invite good fortune. 'T The witches in Shakespeare's play Macbeth could be seen to have been inspired by Celtic sources.

Prayers of protection are equally plentiful in the tradition since, as well as recognizing all creation as theophany, the Celt was also thoroughly aware of impending dangers that threatened from every direction. Threats to one's person, body and soul as well as one's land, family and community could come from pernicious sources. There is a strong urge to draw a shield around oneself as protection against "all cruel and merciless force / that may attack my body and my soul". It is interesting how traditions of penance in early lrish monasticism paid particular attention to evil inclinations which incurred practices of extraordinary asceticism such as standing up to one's neck in ice cold water and surrendering one's body to a bed of nettles.

The prayer entitled 'The Breastplace of St Patrick' or the Lorica of Patrick epitomizes perhaps, the central insight of Celtic Christianity which moves beyond, but does not lose sight of its pagan past. Timothy Joyce OSB sees it as a prayer 'alive with the power of God' [... 'enmeshed in the Trinity' and in the immanence of a loving God. The goodness of creation is laced with the infinite power of God. ${ }^{8}$

- Sylvie Muller, "Wren Ritual in Ireland", quoted in Ó Duinn, 39.

7 We have the well known folktale of Fionn McCool (the strong warrior of the Fianna) whose army of Fianna dug into the mountain, Sliabh Gullion, to obtain for him the magic potion destined to restore him to full vitality when an evil spell had been cast upon him by the wicked Hag of the mountain.

8 Timothy Joyce OSB, Celtic Christianity: A Sacred Tradition, A Vision of Hope Maryknoll, New York: Orbis Books, 1998, 71. 
Such prayers were intended for ritual repetition as if each piece of lorica draws the shield of Christ's protection, piece by piece around oneself. ${ }^{9}$ If it were not firmly founded in early lrish Christianity, this prayer might have been mistaken as a spell for the donning of a magic cloak of protection. It is interesting how the Harry Potter series of books, conceived and written by A.K Rowling, reverts to ancient religious practices to entrance the children of today.

I gather to myself today

The strength of God to guide me

The power of God to uphold me

Wisdom of God to lead me

The eye of God to hear me

The word of God to speak for me

Hand of God to guard me

The full edition of this litany-like sequence represents a call on the omnipresence of Christ to act as shield, to protect and defend the traveler or the one faced with physical or moral danger. Ancient Gaelic sources refer to it as the prayer of the six directions. ${ }^{10}$
Christ be with me, Christ before me
Christ behind me, Christ within me
Christ beneath, Christ above
Christ on my right hand, Christ on my left
Christ in my sleeping, Christ in my rising
Christ in the heart of everyone who thinks of me...

Since similar prayer formulae are found in Hindu Scriptures, the Celtic lorica makes an interesting parallel with aspects of Hindu spirituality. It is a prayer firmly rooted in the many powers of creation, yet invoking the incarnation of Christ and all who have achieved holiness in the new dispensation. The mystical power of this prayer so 'Christ-ian-ates' one's whole being that one can feely call on sun, moon, lightning, fire, wind, ocean, earth and rock as allies in Christian warfare against evil. There is a one-ing of self and community through, with and in Christ. It could be asserted that devout recitation of the Deer's Cry raises the soul beyond mystical

9 A lorica was a kind of protective corselet made up of separate pieces, sometimes of leather, sometimes metal or enamel and assembled and attached to one another to make a shield, by hooks or stitches. In French it was called cuirasse.

r Ó Duinn, Where Three Streams Meet: Celtic Spirituality, Dublin, Columba Press, 2000, 77.79 
boundaries by means of the illusive Celtic imagination which Deane says: "twists and turns through a sensuous spiritual energy, an asymmetrical symbolic language [...] always anti-classical, anti-representational, anti-rational: All is flux and becoming."

What is significant in these early Celtic prayers is that they retained a holistic vision of life, which the rest of Europe was beginning to lose in the Middle Ages. Their sentiments held all things together under the caring eye of God and disposed the pray-er toward a more mystical prayer posture. The most famous exponent of this integrated vision of things must surely have been Don Scotus Eriugina (9th century Irish Christian philosopher and mystic), whose 'unified vision of reality' influenced many European thinkers and mystics of Medieval Europe though he himself came under the cosh in $855 \mathrm{AD} .{ }^{12}$ The Celtic understanding of the world was imaginative, mystical and symbolic and had much in common with Asian and Eastern Churches. It often clashed with the Roman mindset which was literal, practical with leanings towards abstract conceptualization. Little wonder that Eriugena's integrated vision was dismissed as heretical and referred to as, 'Irish porridge' since it attempted to include everything under God.

\section{Nert or Neart}

Macquarie's notion of 'The God-intoxicated Celt' seems to be based on the dynamism of an all-permeating energy that infused all things and toward which the Celt was particularly sensitive. This all pervasive energy that coursed through all things is given serious study by the Benedictine scholar of early and modern Irish, DrSeán Ó Duinn. ${ }^{13} \mathrm{He}$ points to the ancient Irish word nert which literally means 'energy' or 'power' and still exists in spoken Irish as neart. ${ }^{14}$ This free flowing shape shifting energy was strong in the consciousness of the pagan Celt and was seen to permeate all living things. It could magically change shape from animal to human and back again. Something of this flexibility of form making an intricate web of animated energy can be seen in ancient Irish manuscripts such as The Book

" John F.Deane, The Work of Love: Incarnation, Ecology \&Poetry, Dublin, Columba Press, 2010) 21-27, 26.

12 Timothy Joyce, Celtic Christianity: A Sacred Tradition, a Vision of Hope, Maryknoll, New York: Orbis Books, 1998, 57-61.

13 Nert literally means 'energy' or 'strength' which is in its earliest pagan understanding is a dynamic power that permeates the whole earth for good and evil.

14 Ni neart go cur le chéle is a proverb that says: 'real strength is united strength'. 
of Kells and the Book of Armagh. This genre of colourful intricate Celtic design seems to indicate an Indo European influence.

The notion of nert is probably derived from a primordial Creation Myth which invests the universe with fecundity and divine energy. As pagans, the Celts were deeply religious in their veneration of an unknown source of power that inhabited the land. This undifferentiated religious sense emanating from 'a life-force that flowed through all things' was foundational to the earliest phase of Celtic religion. ${ }^{15}$ Ó Duinn proceeds to trace two further stages of development before nert became fully Christianized in Celtic Christianity. ${ }^{16}$

One of the earliest poems written in the vernacular in Ireland was Amergin's ninth century incantation calling on divine power to calm the seas. ${ }^{17}$ It evoked this first stage of nert: a sense of unity in all the elements ruled over by a divine power. Later this poem was interpreted by Christianity as speaking directly of a Christian God. Whatever God is evoked, it is clear that the combined energies of earth, air, fire and water are identified in the godhead which in turn suffuses all elements with divine nert. Divine power is all pervasive.

\section{I am the Wind that blows over the sea \\ I am a Wave of the Ocean \\ I am the Murmur of the billows \\ I am a hawk on the high cliff edge}

The second phase of the development of nert evolved into a personification of this energy, into a multitude of elemental gods and goddesses. The sun god Lugh was reverenced through the Celtic universe and gave its name to places as diverse as Lyons (Lugudunum) in France, London (Lughdenium) in Britain and County Louth (Co Lú) in Ireland. The pagan god Lugh also gives his name to the eight month Lughnasa, the harvest month which gave rise to dancing rituals such as those seen in a recent film based on a play by Brian Friel entitled: Dancing at Lughnasa. ${ }^{18}$

15 Quoted by Ó Duinn, Where Three Streams Meet 2000, 85.

16 This sense of a all-pervasive divine presence is not peculiarly lrish, it is present in most primitive cultures. It is found at Zuma Rock in Nigeria, West Africa where photography is forbidden and seen as a violation of a sacred place. Similarly, intuitions of the spirit that pervades Ayers Rock in Australia are strong and in India, of course, in a myriad of sacred shrines and in particular in the sacred mountain of BODH GAYA.

1 'Amergin's Song', Thomas Kinsella ed., The New Oxford Book of Irish Verse, London: Oxford University Press, 1986, 48, 395.

13 First directed by Joe Dowling as a play in the Abbey Theatre Dublin, 1990 and later produced as a film in 1998 with Meryl Streep in the role of Kate Mundy and Pat $O^{\prime}$ Connor, Producer. 
Lugh also bestowed the fire of magic and artistic inspiration. ${ }^{19} \mathrm{~W}$.B. Yeats gives a modern rendition of this poetic fire in his 'Song of Wandering Aengus': 20

I went out to the hazel wood

Because a fire was in my head

Traces of ancient elemental gods and goddesses have left their marks on many Irish place names. The name of Éire itself, the official name of Ireland, derived from a goddess whose betrothal to the king of Ireland was a guarantee of fertility for the land. ${ }^{21}$ Irish rivers' names are derived from goddesses: the Shannon, The Boyne, The Eirne while mountains and seas had their deities to whom sacrifice was offered. The river goddess of the Boyne River was central to sun-ceremonies surrounding the Neolithic passage tomb at Newgrange at the winter solstice. The first ray of winter sun entering the roof-box of this prehistoric tomb is a powerful reminder of a prehistoric belief in elemental gods who promised perennial triumph over death along with renewed fertility of the earth.

At a third stage of spiritual evolution, these gods/goddesses gave way before Patrician Christianization with its Trinitarian emphasis. The coming of Christianity to Ireland, as early as the third and fourth century and its continued success relied on a comprehensive conversion from a plethora of elemental gods that dominated the landscape, to the One God who ruled over all the elements, the King of the Universe, given a new name in prayer and invoked poetically as Ri na nDúl. Patrician Christianity had the genius to use what was best in the old dispensation along with the people's natural reverence of natural beauty to become the cornerstone of the new religion. Christian prayers now, as we have seen above, celebrated a benevolent God who loved the world, was deeply in tune with all aspects of creation and thoroughly invested in everyday life. The Trinity become a strong feature of this era, since it suited the Celtic love of triads. Once see something of its survival today in the national symbol of the shamrock, although undoubtedly a later addition to Irish religiosity. Patrician spirituality coupled with the Celtic monastic movement

19 Patrick Kavanagh ( 1904-1967) The Green Fool, London: Penguin Books, 1975, 201-201

The poet claimed that when poetically inspired, he was touched by a spark of the divine that impregnates the poet so as to bring forth immortal words. He is equally likely to say that in the act of writing, he is 'baptized by fire and by the Holy Ghost'.

a W.B.Yeats, Collected Poems ed. Augustine Martin, 'Song of Wandering Aengus' (London: Arena Books, 1990), 55-56.

2 Lebor Gabála Érenn (The Book of Invasions) is the Middle Irish title of a collection of prose and poetry recounting the mythical origins and history of the Irish race from the beginning of the world down to the Middle Ages. It was compiled and edited by an anonymous 11th century scholar. 
seemed capable of integrating much of the riches of a pagan past into its spirituality. This explains the enormous success of Celtic Christianity and its missionary outreach.

What was the outcome of this radical transformation and did anything remain of the once ubiquitous religion? The kingdoms of these early elemental gods, mountains, rivers, islands and wells, retained their reputation as holy or 'thin places' the phenomenon called 'caol áit(acha)' dotted across the landscape, easily appropriating the names of Irish saints: Brigid, Patrick, Colmcille, Éanna, Finbar etc. all became places renowned for Christian pilgrimage and places of piety. Shrines once religious in the older dispensation became transformed into healing wells, sacred mountains, holy islands. It is no longer Lúgh, or Manannan, (God of the Sea), Eithne, Méabh, Úna or Dana of the hills who command veneration, but a conscious awareness of these 'thin places' lived on commanding reverence and a desire for pilgrimage and penance. Celtic Christianity had no difficulty in embracing the notion of pilgrimage and penance: Croagh Patrick, Lough Derg, Clonmacnoise. Glendalough, Faughart and Guagán Barra and several Ladywells: these still testify to practices which have survived with or without the blessing of the official churches.

Prehistoric Nert has been finally transformed into a personal immanent God, and into a Christ who offers shield and protection for each day. The Celtic God is both 'beyond the beyonds' yet immanently present and fully engaged in daily life.

\section{Poets are often Sensitive to Transcendent Energy}

The power of 'nert' is still detectable in certain modern Irish poets, featuring certain poetic affirmation of radiance, epiphany, numinous presence emanating from creation. The patriot poet Joseph Mary Plunkett [1887-1916] senses the visible trace of God's beauty around him:

I see his blood upon the rose

And in the stars the glory of his eyes

His body gleams amid eternal snows

His tears fall from the skies. ${ }^{22}$

A later poet Patrick Kavanagh [1904-1967] in whose work is found, hints of a mystical imagination, expresses delight at God's beauty bursting out in backward

22 I See his Blood upon the Rose', The Deer's Cry: A Treasury of Irish Religious Verse ed.Patrick Murray, Dublin: Four Courts Press, 1986, 195. 
places redolent with God's beauty. At another time, he sees God breathing his love in the riotous colours of a flowering bog:

Green, blue, yellow and red

God is down in the bogs and marshes...

Beautiful, beautiful, beautiful God

Is breathing his love by a cutaway bog [The One] ${ }^{23}$

Nert seems to be alive and well in his work when, in his fictional alter-ego character Tarry Flynn, he exclaims that his spring landscape is alive with the Holy Spirit. ${ }^{24} \mathrm{He}$ may indeed be a good example of 'the God-intoxicated Celt' who, by his unorthodox behaviour, dismayed his farming neighbours and even his mother by the possibility that he might be half-mad. ${ }^{25}$ We have already noted that W.B. Yeats considered poetic inspiration as 'a fire in the head' much as Kavanagh believes that his best work has within it 'a spark of divine energy' vestiges of Lugh or Bel, the Celtic firegods. Lest we imagine that this unseen energy is always positive, Yeats senses the dark energy of defeat crossing the lrish landscape as 'a bitter black wind that blows from the left hand'. ${ }^{26}$ And in a much more earthy way, in his 'Great Hunger' epic, Kavanagh saw an apocalypse of clay haunt every corner of the land. Kavanagh also saw the primitive all pervasive sacred pagan energy in the Celtic tradition suffused throughout the land.

\section{'Thin Places' or the Phenomenon of the 'Caol Ait'}

The Celts had a strong belief in the after life. ${ }^{27}$ At special places and times of the calendar year, when the veil between this world and the next was only barely drawn; these moments became designated as 'thin places'. Certain well defined landmarks like Samhain (Nov $7^{5}$ ) brought the summer season to a close and opened up the

3 Patrick Kavanagh, The Complete Poems Ed, Peter Kovanagh, (Newbridge, Ireland: The Goldsmith Press, 1984) 291. Unless othenwise stated all quotations from this poet's work are taken from this edition of his works.

24 Patrick Kavanagh Tarry Flynn, Middlesex, England: Penguin Books, 1978, 29-30.

25 Una Agnew, The Mystical Imagination of Patrick Kavanagh: A Buttonhole in Heaven, (Dublin: The Columba Press, 1998, 1999) 187.

x W.B.Yeats, Collected Poems ed. Augustine Martin, 'Red Hanrahan's Song about Ireland', London: Arena Books, 1990, 77.

I Listening to his neighbours' appraisal of a newly buil house, the writer Patrick Kavanagh (1904-1967) concluded that Irish people never forget they must die since the main conversation indicated that the doonway was not sufficiently wide to allow for the passage of a coffin from its precincts and that exit through a window would be necessary. 
darker half of the year. At this transition time, the souls of the dead were understood to congregate with the living. A sense of spirit haunted the land. There is a strong hint of Celtic Underworld that permeates Irish consciousness at these times, so that family graves become places of veneration. At solstice and equinox times ancient Neolithic tombs became gathering places where people gathered to worship the sun's perennial triumph over darkness and its undying status as God of the earth. Similarly, Bealtaine (May Ist) closed the veil of winter and opened the new season with a procession of divine spirits and dance rituals around the new fire of the God Bel, author of new life and fertility. Thin places gave rise to further experiences of the 'god intoxication' to which Macquarrie referred, thereby opening up the boundaries of mysticism a little wider afield.

Celtic Christianity brought a similar sense of well-established semi-permeable soulplaces places such as: lona in Scotland, Glendalough, Croagh Patrick and Lough Derg in Ireland. Since Celtic civilization had married very well into the Brehon Law tradition, where the tuath was the unit of land ruled over by a Celtic chieftain, the abbot of the monastery became the new tuath and spiritual leader of the community. In the golden age of Irish Christian monasticism, the abbot gathered monks around him so that monasteries became places of pilgrimage and holy learning under the saintly guidance of saints such as: Ciaran, Finian, Colmcille and Kevin. Holy places such as these developed into a whole series of 'thin places' renowned for holiness where the presence was palpably felt. Holy wells, High Crosses, holy mountains, ancient burial sites, lone bushes: all were treated with the utmost respect and reverence, hence the popularity still of pilgrimages to Lough Derg, Croagh Patrick, Clonmacnoise, Glendaloch. Iona in Scotland and Lindisfarne or Holy Island off the north east coast of England are all well established 'thin places'.

In postmodern times, now that the ancient aura of Ireland as the Island of Saints and Scholars is well and truly banished, the spirituality of the thin place or caol ait still persists. It can be recognized in the 'glimpse', 'the chink' or wisp of eternity that somehow escapes or emanates from what the poet Kavanagh calls 'the bits and pieces of everyday' ${ }^{28}$ Poetry offen records these glimpses of eternity which ordinary mortals may dismiss fanciful. Mark Patrick Hederman hails contemporary poetic and artistic expression as the 'underground cathedrals' being built in our culture. Rather boldly he declares:

At this time the secret work of the Holy Spirit is not being done in most countries of Western Europe by politicians nor by church institutions. The people who are carrying the torch are not mostly artists...nor does

a Patrick Kavanagh 'The Great Hunger' Complete Poems, 79-104, 84. 
it matter how much that work goes unrecognized... (since) That has been the profile of the Holy Spirit since the beginning of time. ${ }^{29}$

Irish people are beginning to recognize the prophetic role played by their poets. In his poem 'A Christmas Childhood' Kavanagh speaks of his glimpse of eternity set in the context of humble haggard on a small farm: "The light between the ricks of hay and straw was a hole in heaven's gable. ${ }^{\prime \prime 3}$ In a later poem he finds himself caught unaware in the stare of 'Fantastic light [that] looks through the eye of bridges'. ${ }^{31}$ When Kavanagh asserts that 'revelation comes as an aside', he indicates that there are moments of knowledge and vision that are beyond reason..$^{32}$

The Welsh poet RS Thomas (1913-2000) presents a classic example of the wisp of God in an out-of-the-blue glimpse of eternity caught in the poet's memory as 'the sun breaks through to illuminate a small field'. Recollecting the moment in tranquility afforded by his poetic skill, he likens to 'turning aside like Moses to the miracle of the lit bush'. These are hints of mystical awareness which parallel the earlier more established experiences of 'thin places' where God's presence is near. ${ }^{33}$

The current Irish Nobel Laureate Seamus Heaney (1938-) shows he is not unaware of such moments of heighted sensibility when a sense of the powerful impact of nature is seen to have the effect of blowing open the heart that is caught 'off guard'. Such a moment hints of something beyond the ordinary a moment of expanded consciousness which poet and mystic share alike.

And sometime make the time to drive out west

Into County Clare, along the Flaggy Shore

In September or October, when the wind

And light are working off each other...

You are neither here nor there,

A hurry through which known and strange things pass

A big soft buffetings comes at the car sideways

And catch the heart off guard and blow it open. ${ }^{34}$

P Mark Patrick Hederman, Underground Cathedrals, Dublin: The Columba Press, 2010, 140$156,141$.

30 'A Christmas Childhood' The Complete Poems of Patrick Kavanagh, ed. Peter Kavanangh, 143-144.

3 Complete Poems of Patrick Kavanagh, 295.

D See also Patrick Kavanagh, 'To Hell with Commonsense' Complete Poems, 288.

3 R.S.Thomas, Later Poems 1972-1982, London: Macmillan Papermac, 1983, 81.

अ Seamus Heaney, 'Postscript' in: Spirit Level, London: Faber and Fabler, 1996. 
Today these poetic glimpses may be all that remain of the ancient 'thin places' that brought people nearer their God.

\section{The Lios or Fairy Fort or Rath}

Another influential spiritual and mythical phenomenon that consciously or unconsciously continues to permeate the Irish psyche is that of the predominance of the lios or ring-fort on the landscape. These are circular stone-walled spaces generally located on the tops of small hills or hillocks and scattered across the face of Ireland. They date from 1200BC to $400 \mathrm{AD}$, remnants of a prehistoric farming people, most likely of Celtic origin. These are built with circular or oval shaped enclosure stone ditches to provide home and animals with a measure of protection against adverse forces from without. Inside, souterrains were dug as hiding places and as refrigeration for food preserved there throughout the year so that a kind of enclosed circle of life was lived at the heart of the lios with good look out facilities over the neigbourhood. An estimated 30,000 of these ringforts with place names to match beginning with Rath or Lios, survive as conspicuous Irish landmarks today. It would not be an exaggeration to say that almost every farmer has a lios or rath somewhere on his farm. ${ }^{35}$

To further consolidate the lios as an otherworldly fairy place, an ancient mythical history of Ireland recounts the waging of war between two mythical tribes one human and one divine who strove to take ownership of the land. These two powerful tribes fought for possession and the end result was that the wizardly tribe, the Tuatha dé Danainn lost the upper hand and division of the land was imminent. In settling boundaries the fairy folk opted for the underground half of the land allocating to themselves the hollows of the hills and the megalithic sites and passage graves while the conquerors opted for the surface of the land. And so it was that the divine geniuses the Tuatha dé Danainn, descendents of the gods appropriated the hollows of the hills but still retained a certain control over the fertility of the land. ${ }^{36} \mathrm{~A}$ host of customs arose whereby sacrifices of corn, milk and butter were offered to the hidden lucht si who made their appearance at deaths, marriages and births and took their revenge on the crops when badly treated. So it was that a truce was made and the fairies or lucht si agreed to live in peaceful coexistence with the conquerors provided certain sacrificial donations were duly made. And so this multifude of lioses and

5. Hill forts were in use in many Celtic areas of central and Western Europe until the Roman conquest. Julius Caesar described the large late Iron Age hill forts he encountered during his campaigns in Gaul as oppida.

3 Ó Duinn, 2000, 55-61. 
raths throughout Ireland became known as fairy forts. People working on the land, learned to tread carefully on these ancient sites so that no one would dare disturb a lone bush or a fairy tree. There is still a strong taboo around these places and a belief it would bring bad luck to disturb their fairy tenants. Ironically, it now transpires that these clumps of fairy trees and lone bushes are ecological treasure for the pollination of crops.

Nuala Ní Dhómnaill, a contemporary Irish poet, insists that the lios is not only a physical landmark on the landscape but holds a space in the people's and in the poet's psyche. ${ }^{37}$ This fairy-fort-within, houses the stuff of the gods and belongs to the sacred underworld. The poet is still obliged to be the messenger of Hermes, the winged god, and stay on the track of the gods who are being banished from the earth by materialism. The lios may be no more than a clump of trees on a hilltop; nevertheless it is symbolic of an inner place sacred to the gods. Stories and legends abound in relation to these fairy places. Ní Dhomhnaill believes that it is the poet or soothsayer who brings the stuff from that other world into the world of here and now so that the people are given access to its fairy or mystical power. 'When I write a poem', she says, 'I experience inspiration and a sense of being impregnated by the divine'. Many poets believe that the mystic and poet share moments of expanded consciousness that are similar. ${ }^{38}$ What they do with these moments afterwards may differ, though not always.

\section{Summary and Conclusion}

When examined historically and in dialogue with well scrutinized ancient texts by scholars who are competent in the languages of these texts, it would appear that there is a long tradition in Ireland of celebrating earth as theophany. The Celts may not have built a political empire; instead they left behind them a spiritual legacy which emphasized hierophanies over dynasties. The marriage of Celtic nature worship with Christianity was most successful where it integrated the best of ancient beliefs with faith in a Triune God. In the golden era of Irish monasticism a host of holy monks, men and women dedicated themselves to the study and illumination of God's word in manuscript as well as God's word 'spoken' in creation and in the green church of the out-of-doors. The prayer practice of the ancestors left

3 Kimberly R. Myers, Nuala Ni Dhomhnaill and Women's Sensual Spirituality' in: Things of the Spirit: Women Writers Constructing Spirituality, ed. Kristina K.Groover, Notre Dame, Indiana: University of Notre Dame Press, 2001, 303-304.

3 Doreen Gildroy, 'Poetry and Mysticism' in: The American Poetry Review, Mar/Apr 2009, 39. 
behind an oral legacy of holistic spirituality and a benediction of each moment of each day sufficiently robust to support mystical prayer. Could this be called 'God intoxication' probably not. Nevertheless, pockets of continuous prayer survived to demonstrate a strong sense of God attuned to all events and occasions, however commonplace. If 'God-intoxication' occurred it was because life was embraced on all sides as Divine mystery. These kinds of people, Mircea Eliade believed, saw themselves in a godlike role, tilling the soil in tandem with divinity. ${ }^{39}$

When sacrality is banished from the earth by consumerism and materialism, it is the poets who stay on the tracks of the fugitive gods. ${ }^{40}$ Today it seems that the Holy Spirit works incognito among the poets and artists, mining the gold of 'thin places' and interior lioses which keep alive epiphanies of divine life as well as wisps of transcendence that might otherwise be lost. Even with the rapid arrival and departure of the so-called 'Celtic tiger' in Ireland and the threat that consumerist values would predominate, poets still show the way forward and help their audience retain a sense of transcendence and a continuous acknowledgement of the sacramental dimension of creation. John $O$ Donohue showed himself to be a writer preeminent in allowing his consciousness to be seized by the numinosity of something in the landscape beyond himself. He experienced frequent sensations of blessedness or epiphany. ${ }^{41}$ Thus imagination, poetry and ascetical practice continue to consolidate in the psyche a strong religious sense.

I will conclude with a quotation from the poet Kavanagh who has already featured in this essay. Poetically he expresses the epiphany of a moment trapped in mystery. On a cold dismal March day, the sun breaks through so that a tree on the horizon becomes suddenly infused with an eternal radiance. The poet captures the moment, through the eyes of a simple farmer (probably himself) who is ploughing a field, in the inhospitable east wind. Everything seems cold, infertile, comfortless, and Godforsaken. Yet, in the twinkle of an eye, the poet finds himself caught up in a Trinitarian moment which binds together earth, tree, sky, the people and heaven.

The pull is on the traces it is March

And a cold black wind is blowing from Dundalk...

Yet sometimes when the sun comes through a gap

These men see God the Father in a tree

刃 Mircea Eliade, Patterns in Comparative Religions, Chapter VII "Earth Woman, Fertility", Bison Books, University of Nebraska edition, 1996. 263-69.

- Martin Heidegger, 'What are Poets for?' Poetry, Language, Thought, New York, 1971, 71.

4 J) John ODonohue, Anam Chara: Spiritual Wisdom from the Celtic World, London: Bantam Press, 1997, 44, 82. 
The Holy Spirit is the rising sap

And Christ will be the green leaves that comes

At Easter from the sealed and guarded tomb. [The Great Hunger Stanza V]

Whatever this moment of expanded consciousness may be, it is a space which mystic and poet share, each in his or her own way. Intoxicating? Perhaps not, but heartwarming, yes! 